Dept. of Animal \& Clinical Nutrition,

Faculty of Vet. Medicine, Assiut University

\title{
EFFECT OF HIGH ENERGY DIET WITH DIFFERENT PROTEIN LEVELS ON THE GROWTH PERFORMANCE AND CARCASS TRAITS OF JAPANESE QUAILS
}

(With 6 Tables)

By

\section{G.M. MOSAAD, H.A. ABDEL-RAHEEM and A.N. SAYED (Received at 10/3/2009)

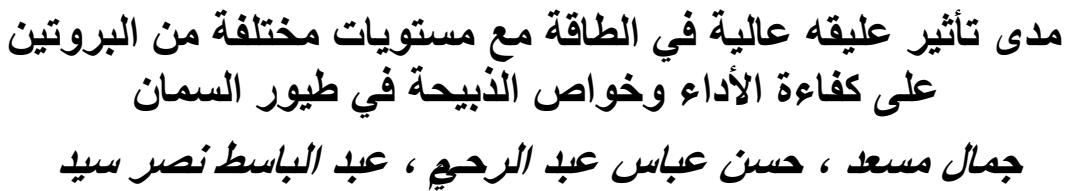

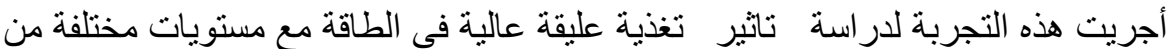

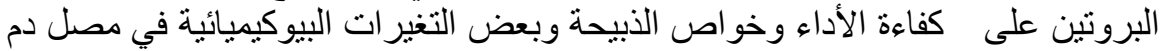

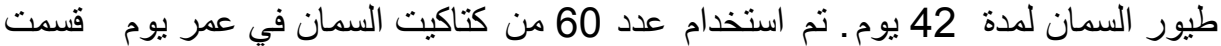

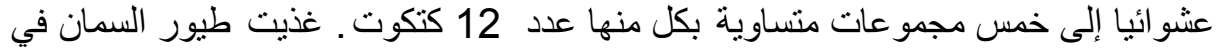

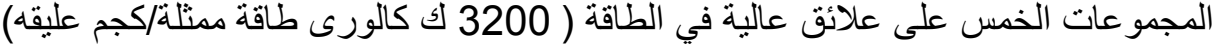

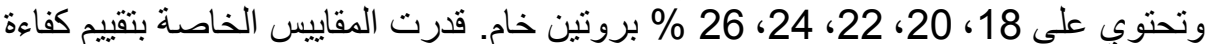

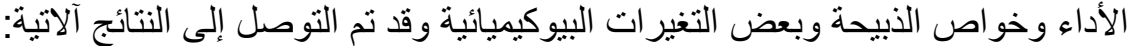

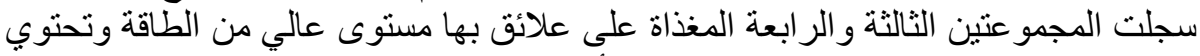

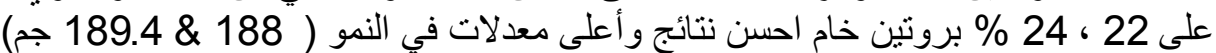

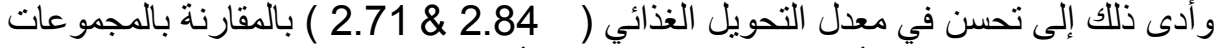

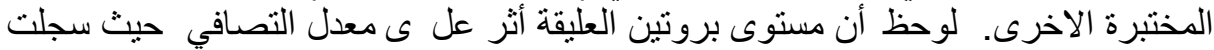

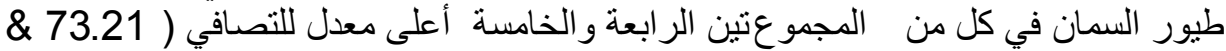

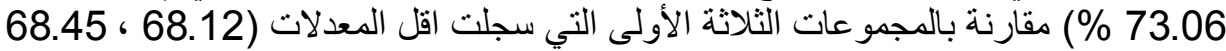

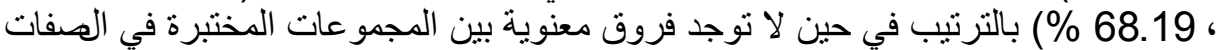

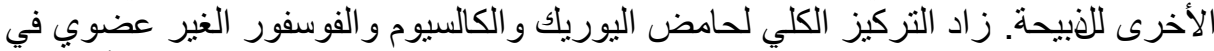

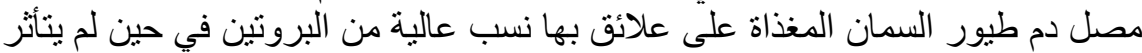

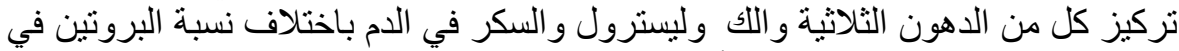

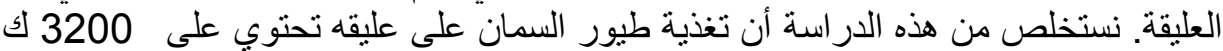

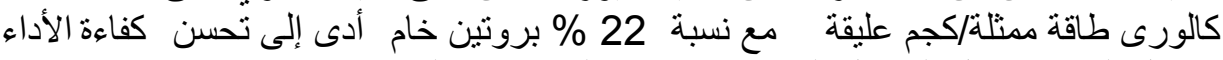
ومعدل النمو ومعامل التحويل الغذائي بالإضافة إلى تحسين الجدوى الاقتصادية.

\section{SUMMARY}

The chick performance, carcass traits and some blood biochemical parameters of Japanese quails fed high energy diet containing different protein levels were studied for 42 days. Sixty quail chicks at hatch 
(average weight $7.02 \mathrm{~g} \pm 0.12$ ) were randomly distributed into five experimental groups (12 chicks/each). Quails in the five groups were fed ad libitum on the respective isocaloric experimental diets $(3200 \mathrm{kcal}$ $\mathrm{ME} / \mathrm{kg}$ diet) containing five dietary protein levels (18, 20, 22, 24, $26 \%$ ). The growth performance, carcass characteristics and some blood biochemical parameters were assessed. The results showed that, quails fed on high energy diets containing $22,24 \%$ protein in the third and fourth groups achieved significantly $(\mathrm{P}<0.05)$ better results, and recorded highest gains $(188.0 \& 189.4 \mathrm{~g}$, respectively) with lowest feed intake. Highest weight gain averages with greatest values of feed conversion $(2.84 \& 2.71)$ were recorded in the third and fourth groups of quails, respectively. Dressed carcass as a percentage of live body weight was maximum in quails offered high protein diets in the fourth and fifth groups $(73.21 \& 73.06 \%)$, while the lowest were recorded in the first three groups fed low protein diets $(68.12,68.45$ \& $68.19 \%$, respectively). Dietary protein levels had no significant $(\mathrm{P}<0.05)$ effect on the internal organ weights. Uric acid, calcium and inorganic phosphorous were increased significantly $(\mathrm{P}<0.05)$ with increasing dietary protein levels, while had no significant effect on serum triglycerides, cholesterol and glucose. It could be concluded that, quails fed on diet having $3200 \mathrm{kcal} \mathrm{ME} / \mathrm{kg}$ with $22 \%$ crude protein, supplemented with limiting amino acids, recorded the best results in weight gain and feed conversion, in addition to economical feed efficiency.

Key words: Quails, performance, carcass traits, protein levels

\section{INTRODUCTION}

Japanese quails (Coturnix coturnix japonica) are fairly resistant to diseases, and impart less worry for vaccination. Because of low volume, low weight, less feed input and space requirements, the commercial quail farming for table egg and meat production can be started with much lower capital investment as compared to chickens and ducks with almost the same profit margin (Kaur et al., 2008). With shorter reproduction cycle and earlier marketing age, it offers fast monetary circulation ultimately yielding quicker returns. The meat production performance of Japanese quails has also been improved during recent years due to genetic selection. Therefore, there is need of updating optimal nutritional requirements of Japanese quails with the improvement in genetic make up to exploit production potentiality. The 
protein quantity and quality are the main factor limiting the animal performance. Traditionally, the levels of crude protein and total essential amino acids are criteria for least-cost feed formulation for monogastrics. In recent years, the model for ideal protein (Baker \& Han, 1994; Emmert \& Baker, 1997; Baker, 2003) is more widely applied by the poultry nutritionists. Establishing requirements of limiting amino acids and supplementing those accordingly in diet through their synthetic form matching the requirements provides scope to reduce dietary protein content. In low protein maize-soybean meal based diets of growing Japanese quails, methionine and lysine are the most limiting amino acids. Generally the crude protein content in diets of growing quails ranges from 24 to $27 \%$ that can be reduced through supplementation of the limiting amino acids as their synthetic forms (Weber \& Ried, 1967; Vohra \& Roudybush, 1971; NRC, 1994; Baldini et al., 1995; Shrivastava \& Panda, 1999). Protein level in the ration of quails is considered as an important factor for the efficient growth but recent studies have shown that besides the protein level, the amino acid profile of feed is more important. The total protein needed for growth actually is based upon the requirement for the dietary essential amino acids and the amount of nitrogen necessary for the biosynthesis of dietary non essential amino acids in the body (Riaz \& Alam, 2006). The main factors determining the production cost of quails are growth rate and feed cost per unit of growth. Feed contributes to about $60-70 \%$ of the total cost of bird production (Vohra, 1993). One of the most expensive major nutrients in a poultry diet is its energy content. Energy alone contributes to about $70 \%$ of the total cost of poultry diets (Skinner et al., 1992). The recommended energy level for growing quail was $2900 \mathrm{kcal} / \mathrm{kg}$ diet (NRC, 1994). High-energy broiler diets are recommended to achieve maximum weight gain and optimal feed conversion ratio (Saleh et al., 2004). Indeed, feed efficiency is influenced by changes in dietary energy concentration in two partially dependent pathways. Firstly, as dietary energy increases, less feed is taken in to satisfy the energy need. Secondly, growth rate is promoted by increasing levels of dietary energy (Palvnik et al., 1997 and Dublecz et al., 1999). The present study was conducted to evaluate the effect of high-energy diet containing different levels of crude protein on the growth performance, carcass traits and some blood constituents in Japanese quails.

\section{MATERIALS and METHODS}




\section{Experimental chicks and housing:}

Sixty quail chicks at hatch (average weight $7.02 \mathrm{~g} \pm 0.12$ ) were randomly distributed into five experimental groups (12 chicks/each), housed in battery cages and kept under similar environmental and managerial conditions during the experimental period. Temperature was set at $35^{\circ} \mathrm{C}$ during the first week and gradually reduced by $2.5^{\circ} \mathrm{C}$ per week to reach $25^{\circ} \mathrm{C}$ at $6^{\text {th }}$ weeks of age. Each cage was equipped with feed and conical water troughs. This experiment was carried out at Faculty of Veterinary Medicine, Assiut University.

\section{Diets and Feeding:}

Five isocaloric experimental diets (3200 kcal ME/kg) included corn-soybean meal basal were formulated to contain five dietary protein levels $(18,20,22,24,26 \%)$ and fed to the quails throughout the experimental period which extended for 6 weeks. Synthetic methionine and lysine were used to balance their contents in the diets. The physical and chemical composition of the experimental diets is shown in Table 1.

Table 1: Physical and chemical composition of the experimental diets

\begin{tabular}{|l|c|c|c|c|c|}
\hline \multirow{2}{*}{ Composition } & \multicolumn{5}{|c|}{ \% CP } \\
\cline { 2 - 5 } & 18 & 20 & 22 & 24 & 26 \\
\hline Physical composition (\%): & & & & & \\
Corn, ground & 61.60 & 54.05 & 46.60 & 39.30 & 32.65 \\
Soybean meal & 27.65 & 34.10 & 40.54 & 46.79 & 52.64 \\
Vegetable oil & 05.73 & 07.10 & 08.40 & 09.70 & 10.80 \\
Ground limestone & 02.30 & 02.30 & 02.25 & 02.20 & 02.10 \\
Sod monobasic $\mathrm{PO}_{4}$ & 01.61 & 01.52 & 01.45 & 01.37 & 01.20 \\
Common salt & 00.30 & 00.30 & 00.30 & 00.30 & 00.30 \\
Premix* & 00.20 & 00.20 & 00.20 & 00.20 & 00.20 \\
Methionine & 00.22 & 00.19 & 00.17 & 00.14 & 00.11 \\
Lysine & 00.39 & 00.24 & 00.09 & $\ldots$ & $\ldots$ \\
\hline Chemical composition (\%) & & & & & \\
Dry matter & 89.67 & 89.83 & 89.98 & 90.11 & 90.23 \\
Crude protein & 18.00 & 20.00 & 22.00 & 24.00 & 26.00 \\
ME (Kcal/kg diet) & 3200 & 3200 & 3200 & 3200 & 3200 \\
Cal/protein ratio & 178.0 & 160.0 & 145.0 & 133.0 & 123.0 \\
Ether extract & 08.26 & 09.43 & 10.59 & 11.56 & 12.46 \\
Crude fiber & 03.20 & 03.57 & 03.86 & 04.13 & 04.40 \\
Calcium & 00.90 & 00.92 & 00.91 & 00.91 & 00.90 \\
Total phosphorus & 00.71 & 00.70 & 00.71 & 00.71 & 00.70 \\
Methionine & 00.50 & 00.50 & 00.50 & 00.50 & 00.50 \\
Lysine & 01.30 & 01.30 & 01.30 & 01.36 & 01.50 \\
\hline
\end{tabular}

* Each $\mathrm{Kg}$ of premix contained vit. A 8.000.000 IU; vit. $\mathrm{D}_{3} 1.600 .000 \mathrm{IU}$; vit. $\mathrm{E} 7 \mathrm{mg}$; vit. $\mathrm{K}_{3} 1.5$ mg; vit. $B_{1} 1.0 \mathrm{mg}$; vit. $B_{2} 3.5 \mathrm{mg}$; vit. $B_{6} 1.0 \mathrm{mg}$; vit. $B_{12} 10.0 \mathrm{mg}$; Nicotinic acid $20.0 \mathrm{mg}$; Pantothenic acid 7.0 mg; Folic acid 1.000.000 IU; Biotin 40.000 IU; Choline chloride 350.0 mg; Mn 40.0 mg; I 0.3 mg; Co 0.75 mg; Zn 40.0 mg; Cu 3.0 mg; Fe 25.0 mg; Se 0.1 mg; Ethoxyquin $5.0 \mathrm{mg}$ and Ascorbic acid $500 \mathrm{mg}$. 
The leg-banded quails in the five groups were fed ad libitum on the respective diets in mash form and given free access to water throughout the experimental period.

\section{Measurements:}

Body weight development $(\mathrm{g})$ and feed intake $(\mathrm{g})$ of quails were recorded on 7-day interval until 42 days of age. Mortality rate was also monitored on group basis. Feed conversion ratio ( $\mathrm{g}$ feed/g gain), protein efficiency ( $g$ protein intake/g gain) and energy efficiency (kcal ME intake/g gain) were calculated every other week. The proximate analysis of the experimental feeds was performed using procedures detailed by the Official Analytical Chemistry (AOAC, 1990).

\section{Carcass traits:}

At the end of the experiment three birds from each group were slaughtered after fasting overnight, processed and the weight of carcass, liver, intestine, proventriculus, gizzard and heart were recorded. Dressed carcass is the weight of the slaughtered birds after removal of feathers, head and feet but including all edible offals. The organ weights were expressed as relative weight proportionate to pre-slaughter live body weight.

\section{Blood samples:}

Blood samples were collected from each bird. Serum was separated by centrifugation at $3000 \mathrm{rpm}$ for 10 minutes and stored at $18^{\circ} \mathrm{C}$ till further analysis. Total serum protein, total lipids, total cholesterol, glucose and uric acid were determined using standard kits supplied by Bio-Merieux (Baines/France). Inorganic phosphorous was determined in serum according to the method of Yee (1968) at $650 \mathrm{~nm}$, while serum calcium was determined after the method described by Lehman \& Henry (1984) at $550 \mathrm{~nm}$ by using spectrophotometer and test kits supplied by Sentinel Chemistry Co. (Milan, Italy).

\section{Economical evaluation:}

Total feed cost, total production cost, price of body weight, net revenue and economical feed efficiency were calculated.

\section{Statistical analysis:}

Statistical analysis of the obtained data was carried out according to procedures of completely random design SAS (1995). 


\section{RESULTS}

Body weight development and mortality rate of the experimental chicks fed high-energy diets containing different levels of protein are shown in Table 2. Groups fed on $22 \& 24 \%$ crude protein were recorded highest values in body weight (194.9 \& $196.6 \mathrm{~g} / \mathrm{bird})$ compared with other treated groups.

Table 2: Body weight development (g) and mortality rate (\%) of the Japanese quails.

\begin{tabular}{|c|c|c|c|c|c|}
\hline \multirow[b]{2}{*}{ Weeks } & \multicolumn{5}{|c|}{ Protein levels (\%) } \\
\hline & 18 & 20 & 22 & 24 & 26 \\
\hline 0 & $7.12 \pm 0.06$ & $6.94 \pm 0.03$ & $6.95 \pm 0.05$ & $7.22 \pm 0.07$ & $6.85 \pm 0.06$ \\
\hline 1 & $23.30 \pm 1.32^{\mathrm{b}} *$ & $24.10 \pm 1.19^{b}$ & $29.40 \pm 1.86^{\mathrm{a}}$ & $31.10 \pm 1.66^{\mathrm{a}}$ & $26.20 \pm 1.43^{\mathrm{ab}}$ \\
\hline 2 & $42.30 \pm 2.36^{\mathrm{b}}$ & $43.90 \pm 2.95^{\mathrm{b}}$ & $51.00 \pm 3.14^{\mathrm{a}}$ & $53.70 \pm 3.46^{\mathrm{a}}$ & $50.80 \pm 3.62^{\mathrm{a}}$ \\
\hline 3 & $71.80 \pm 3.18^{b}$ & $74.80 \pm 5.12^{b}$ & $81.60 \pm 4.86^{a}$ & $89.20 \pm 5.10^{a}$ & $85.60 \pm 5.17^{a}$ \\
\hline 4 & $121.0 \pm 3.68^{\mathrm{b}}$ & $125.3 \pm 5.26^{\mathrm{b}}$ & $133.8 \pm 6.09^{\mathrm{ab}}$ & $139.8 \pm 6.23^{\mathrm{a}}$ & $127.3 \pm 5.78^{b}$ \\
\hline 5 & $153.7 \pm 5.44^{\mathrm{c}}$ & $160.8 \pm 6.12^{b}$ & $171.8 \pm 5.11^{\mathrm{a}}$ & $174.3 \pm 4.32^{\mathrm{a}}$ & $165.4 \pm 5.11^{\mathrm{b}}$ \\
\hline 6 & $176.3 \pm 6.28^{c}$ & $185.6 \pm 7.10^{b}$ & $194.9 \pm 4.87^{\mathrm{a}}$ & $196.6 \pm 6.09^{a}$ & $184.6 \pm 4.82^{b}$ \\
\hline
\end{tabular}

* Figures in the same row having the same superscripts are not significantly different $((\mathrm{P}<0.05)$

The performance characteristics of quails include feed consumption, body weight gain, feed conversion ratio, energy and protein efficiency are cleared in Table 3 . Feed intake was increased in group fed on $18 \%$ protein diet (575g/quail) and decreased gradually till reached $509 \mathrm{~g} /$ quail in the group fed high protein diet (26\%). Weight gain was increased with chick groups fed on $22 \& 24 \%$ protein $(188.0$ $\& 189.4 \mathrm{~g}) / \mathrm{bird})$, while the low protein diet $(18 \%)$ recorded the lowest gain $(169.2 \mathrm{~g} / \mathrm{bird})$. Protein efficiency ratio was increased with group fed high level of protein $(26 \%)$, while energy efficiency ratio increased with low level of protein (18\%) compared with other treated groups. 
Table 3: Chick performance of Japanese quails fed different levels of protein

\begin{tabular}{|c|c|c|c|c|c|}
\hline \multirow[b]{2}{*}{ Item } & \multicolumn{5}{|c|}{ Protein levels (\%) } \\
\hline & 18 & 20 & 22 & 24 & 26 \\
\hline Feed intake $(\mathrm{g})$ & & & & & \\
\hline $0-2$ week & 93.60 & 87.70 & 93.30 & 99.50 & 98.70 \\
\hline 2-4 week & 254.2 & 232.1 & 232.3 & 216.3 & 198.8 \\
\hline 4-6 week & 227.2 & 220.9 & 207.0 & 205.0 & 211.2 \\
\hline $0-6$ week & 575.0 & 541.0 & 533.0 & 521.0 & 509.0 \\
\hline Weight gain $(\mathrm{g})$ & & & & & \\
\hline $0-2$ week & $35.18 \pm 2.14^{\mathrm{b}^{*}}$ & $36.96 \pm 1.17^{b}$ & $44.05 \pm 2.28^{\mathrm{a}}$ & $46.48 \pm 1.92^{\mathrm{a}}$ & $43.95 \pm 2.08^{\mathrm{a}}$ \\
\hline 2-4 week & $78.70 \pm 3.72^{b}$ & $81.4 \pm 2.94^{\mathrm{ab}}$ & $82.8 \pm 3.16^{\mathrm{ab}}$ & $86.10 \pm 3.45^{\mathrm{a}}$ & $76.50 \pm 2.16^{b}$ \\
\hline 4-6 week & $55.30 \pm 3.11$ & $60.30 \pm 2.35$ & $61.15 \pm 2.68$ & $56.80 \pm 2.29$ & $57.30 \pm 2.26$ \\
\hline 0-6 week & $169.2 \pm 5.23^{c}$ & $178.7 \pm 4.12^{b}$ & $188.0 \pm 5.22^{\mathrm{a}}$ & $189.4 \pm 3.46^{\mathrm{a}}$ & $177.8 \pm 3.78^{b}$ \\
\hline Feed conversion & & & & & \\
\hline $0-2$ week & 2.66 & 2.36 & 2.11 & 2.14 & 2.26 \\
\hline 2-4 week & 3.14 & 2.82 & 2.75 & 2.47 & 2.58 \\
\hline 4-6 week & 4.17 & 3.73 & 3.50 & 3.53 & 3.82 \\
\hline 0-6 week & 3.32 & 2.97 & 2.84 & 2.71 & 2.88 \\
\hline $\begin{array}{l}\text { Protein efficiency } \\
\text { (g protein intake/g gain) }\end{array}$ & & & & & \\
\hline $0-2$ week & 0.48 & 0.47 & 0.47 & 0.51 & 0.58 \\
\hline 2-4 week & 0.58 & 0.57 & 0.62 & 0.60 & 0.68 \\
\hline 4-6 week & 0.74 & 0.75 & 0.75 & 0.87 & 0.76 \\
\hline 0-6 week & 0.61 & 0.61 & 0.62 & 0.66 & 0.74 \\
\hline Energy efficiency & & & & & \\
\hline (kcal ME intake/g gain) & & & & & \\
\hline $0-2$ week & 8.51 & 7.60 & 6.78 & 6.85 & 7.19 \\
\hline 2-4 week & 10.34 & 9.12 & 8.98 & 8.04 & 8.28 \\
\hline 4-6 week & 13.15 & 11.67 & 10.84 & 11.54 & 11.78 \\
\hline $0-6$ week & 10.88 & 9.69 & 9.07 & 8.80 & 9.16 \\
\hline
\end{tabular}

*Figures in the same row having the same superscripts are not significantly different $(\mathrm{P}<0.05)$.

Carcass traits including carcass weight, dressing percentages, weights of internal organs proportionate to pre-slaughter live body weight are revealed in Table 4. Level of protein had effect on dressing percentage which increased with high protein level $(24$ \&26\%) in comparison with other groups. Dressed carcass as a percentage of live body weight was maximum in quails offered high protein diets $(24 \&$ $26 \%)$ in the fourth and fifth groups (73.21 \& 73.06\%). The lowest dressed carcass percentages were recorded in the first three groups fed low protein diets $(68.12,68.45$ and $68.19 \%$, respectively). 
Table 4: Carcass traits of Japanese quails fed different levels of protein

\begin{tabular}{|l|c|c|c|c|c|}
\hline \multirow{2}{*}{\multicolumn{1}{|c|}{ Parameters }} & \multicolumn{5}{|c|}{ Protein levels (\%) } \\
\cline { 2 - 6 } & 18 & 20 & 22 & 24 & 26 \\
\hline LBW (g) & $176.3 \pm 6.65^{\mathrm{c}^{*}}$ & $185.6 \pm 7.36^{\mathrm{b}}$ & $194.9 \pm 5.97^{\mathrm{a}}$ & $196.6 \pm 7.12^{\mathrm{a}}$ & $184.6 \pm 5.86^{\mathrm{b}}$ \\
Dressed carcass & & & & & \\
weight (g) & $120.1 \pm 5.18^{\mathrm{c}}$ & $127.0 \pm 6.25^{\mathrm{b}}$ & $132.9 \pm 4.72^{\mathrm{b}}$ & $143.9 \pm 5.49^{\mathrm{a}}$ & $134.9 \pm 4.94^{\mathrm{b}}$ \\
Dressing (\%) & $68.12 \pm 0.27^{\mathrm{b}}$ & $68.45 \pm 0.19^{\mathrm{b}}$ & $68.19 \pm 0.38^{\mathrm{b}}$ & $73.21 \pm 0.28^{\mathrm{a}}$ & $73.06 \pm 0.20^{\mathrm{a}}$ \\
Intestine (\%) & $5.76 \pm 0.06$ & $5.63 \pm 0.05$ & $5.92 \pm 0.05$ & $6.15 \pm 0.09$ & $6.12 \pm 0.07$ \\
Proventriculus (\%) & $0.311 \pm .003$ & $0.319 \pm .002$ & $0.331 \pm .005$ & $0.348 \pm .003$ & $0.356 \pm .004$ \\
Gizzard, \% & $1.82 \pm 0.06$ & $1.82 \pm 0.03$ & $1.87 \pm 0.07$ & $1.93 \pm 0.04$ & $1.95 \pm 0.06$ \\
Liver, \% & $2.13 \pm 0.03$ & $2.17 \pm 0.05$ & $2.16 \pm 0.04$ & $2.39 \pm 0.03$ & $2.20 \pm 0.05$ \\
Heart, \% & $1.25 \pm 0.02$ & $1.28 \pm 0.03$ & $1.32 \pm 0.05$ & $1.36 \pm 0.04$ & $1.36 \pm 0.03$ \\
\hline
\end{tabular}

* Figures in the same row having the same superscripts are not significantly different $(\mathrm{P}<0.05)$

Serum biochemical parameters (total serum protein, triglycerides, total cholesterol, glucose, uric acid, calcium and inorganic phosphorous are presented in Table 5. Uric acid, calcium and phosphorous levels in the serum of quails were increased with increasing level of protein.

Table 5: Serum biochemical parameters in Japanese quails fed different levels of protein.

\begin{tabular}{|l|c|c|c|c|c|}
\hline \multirow{2}{*}{\multicolumn{1}{|c|}{ Parameters }} & \multicolumn{5}{|c|}{ Protein levels $(\%)$} \\
\cline { 2 - 6 } & 18 & 20 & 22 & 24 & 26 \\
\hline Total protein, $\mathrm{g} / \mathrm{l}$ & $27.7 \pm 0.52$ & $28.32 \pm 0.16$ & $29.70 \pm 0.32$ & $30.4 \pm 0.12$ & $30.6 \pm 0.80$ \\
Triglycerides, $\mathrm{mmol} / \mathrm{l}$ & $7.32 \pm 1.6$ & $6.24 \pm 1.11$ & $7.12 \pm 0.58$ & $6.78 \pm 0.47$ & $5.92 \pm 0.37$ \\
Cholesterol, mmol/1 & $6.12 \pm 0.24$ & $5.98 \pm 0.37$ & $6.33 \pm 0.21$ & $5.96 \pm 0.46$ & $6.03 \pm 0.52$ \\
Glucose, $\mathrm{mmol} / \mathrm{l}$ & $16.23 \pm 0.6$ & $15.99 \pm 0.57$ & $17.22 \pm 0.40$ & $16.07 \pm 0.32$ & $16.11 \pm 0.56$ \\
Uric acid, $\mathrm{mmol} / \mathrm{l}$ & $0.39 \pm 0.03^{\mathrm{b}}$ & $0.35 \pm 0.05^{\mathrm{b}}$ & $0.45 \pm 0.03^{\mathrm{a}}$ & $0.52 \pm 0.06^{\mathrm{a}}$ & $0.47 \pm 0.03^{\mathrm{a}}$ \\
Calcium, $\mathrm{mmol} / \mathrm{l}$ & $1.92 \pm 0.18^{\mathrm{b}}$ & $2.01 \pm 0.27^{\mathrm{b}}$ & $2.39 \pm 0.21^{\mathrm{a}}$ & $2.35 \pm 0.18^{\mathrm{a}}$ & $2.65 \pm 0.28^{\mathrm{a}}$ \\
Phosphorus, $\mathrm{mmol} / \mathrm{l}$ & $1.29 \pm 0.06^{\mathrm{b}}$ & $1.38 \pm 0.13^{\mathrm{b}}$ & $1.79 \pm 0.08^{\mathrm{a}}$ & $1.68 \pm 0.11^{\mathrm{a}}$ & $1.65 \pm 0.07^{\mathrm{a}}$ \\
\hline
\end{tabular}

* Figures in the same row having the same superscripts are not significantly different $((\mathrm{P}<0.05)$

Economical evaluation of quail performance in the different experimental groups are presented in Tables 6. The economical evaluation of quail performance fed diets containing 22 and $24 \%$ protein had more economic feed efficiency (82.1 \& 83.2\%) compared with the other experimental groups $(62.9,77.7,65.5 \%)$. 
Table 6: Economical evaluation of chick performance in the different experimental groups

\begin{tabular}{|l|c|c|c|c|c|}
\hline \multirow{2}{*}{\multicolumn{1}{c|}{ Parameters }} & \multicolumn{5}{c|}{ Protein levels (\%) } \\
\cline { 2 - 6 } & 18 & 20 & 22 & 24 & 26 \\
\hline Body weight (g) & 176 & 186 & 192 & 197 & 185 \\
Price of feed (LE/Kg) & 1.83 & 1.90 & 1.98 & 2.06 & 2.15 \\
Feed intake (g) & 575 & 541 & 533 & 520 & 510 \\
Total feed cost (LE) & 1.05 & 1.03 & 1.06 & 1.07 & 1.10 \\
Total production cost (LE) & 1.45 & 1.43 & 1.46 & 1.47 & 1.50 \\
Price of body weight & 2.11 & 2.23 & 2.30 & 2.36 & 2.22 \\
Net revenue, LE & 0.66 & 0.80 & 0.87 & 0.89 & 0.72 \\
Economic feed efficiency & 62.9 & 77.7 & 82.1 & 83.2 & 65.5 \\
Relative economic feed efficiency & 100 & 124 & 131 & 132 & 104 \\
\hline
\end{tabular}

\section{DISCUSSION}

\section{Growth performance:}

There was significant $(\mathrm{P}<0.05)$ difference in the body weight and weight gain between the different experimental groups and the chick groups fed on the dietary protein levels of $18,20 \& 26 \%$ had significant the lower values. The body weight and weight gain of the groups fed 22 \& $24 \%$ protein levels increased significantly $(\mathrm{P}<0.05)$ as compared to the other groups. These agreed with that found by Ozek et al. (2003) and Ozek (2006) who reported progressive growth rates with increasing dietary protein concentration. Satisfactory growth rates were obtained between 24 and $27 \%$ crude protein levels as found in the earlier studies by (Weber \& Ried, 1967; Vohra \& Roudybush, 1971; NRC, 1994; Baldini et al., 1995; Shrivastava \& Panda, 1999). Poultry fed commercial diet with a reduction of 2 units of protein perform as well as better than poultry fed diets containing higher protein levels if the low protein diets are supplemented with the most limiting amino acids (Han et al., 1992; Moran et al., 1992 and Lippens et al., 1997). Concerning the feed intake, there were no differences between the experimental groups during the first two weeks of age, while in the last four weeks of the experiment, feed consumption was clearly reduced in groups fed diets containing $24 \& 26 \%$ protein. For the whole period (0-6 weeks), the lowest and highest feed consumption was found in quails fed the diets containing 26 and $18 \%$ protein, respectively. These results of feed intake are supported by the work of Ozek et al. (2003) and Ozek (2006) who reported that quails fed a diet containing $20 \%$ protein consumed significantly $(\mathrm{p}<0.01)$ more feed than others fed on 22, 24, 26 and $28 \%$ dietary protein. In contrast, Woodard et al. (1977) reported that there 
was linear relationship between feed consumption of pheasant and dietary protein content. The protein content of the diet had a significant $(\mathrm{P}<0.05)$ effect on the feed conversion ratio for the 0-2, 2-4 and 4-6 weeks periods. The feed and energy efficiency of the first group fed low protein diet $(18 \%)$ was significantly $(\mathrm{P}<0.05)$ poorer than other groups fed high protein diets at the same period. Angulo et al. (1993), Djouvinov \& Mihailov (2005), Hashiguchi \& Yamamoto (2006) and Tarasewicz et al. (2006) found that total body weight gain and feed conversion were not affected by dietary protein levels in growing quails. On the other hand, Annaka et al. (1993), Marks (1993) and Hashiguchi et al. (1998) indicated that body weight gain decreased linearly with low dietary protein level in quails. Energy efficiency (kcal ME intake/g gain) was enhanced in the third and fourth groups (9.07 \& 8.8) fed on $22 \&$ $24 \%$ protein. Improvement of energy efficiency resulted in an increasing of body weight gain and feed conversion in quails in these groups. Protein efficiency calculated as $g$ protein intake/g gain was similar amongst the quail chicks fed different protein levels and group fed $26 \%$ protein tended to be more optimally efficient.

\section{Carcass traits:}

The level of dietary protein significantly affect the dressing percentages and the groups fed on the high dietary protein $(24 \& 26 \%)$ recorded the highest values. In this respect, Kul et al. (2006) and Seker et al. (2009) found that the dressing percentages of Japanese quails slaughtered on 45 days old were 67.23 and $70.67 \%$, respectively. Among the internal organ weights, there were no significant difference among groups in weights of intestine, proventroculus, gizzard, liver and heart. The internal organ weights were slightly highest in the fourth and fifth groups fed high protein diets $(24 \& 26 \%)$ compared with groups fed low protein diets $(18,20,22 \%)$. Similar results have been reported by Adeyemo, (2000) who found that increasing CP level in the diets of pullets improved dressing percentage. Also Aggoor et al. (2000) and Ismail et al. (2006) found that high energy diet produced carcass of higher dressing percentage in quails, whilst had no effect on the internal organs. On the contrary Kassim \& Suwanpradit (1996) found that increasing dietary energy or protein did not affect dressing and internal organ percentages.

\section{Serum biochemical parameters:}

Serum biochemical values revealed that uric acid, calcium and inorganic phosphorous increased significantly $(\mathrm{P}<0.05)$ with increasing dietary protein levels. A direct relationship between uric acid and dietary 
protein concentration agreed with Belay \& Teeter (1996) and Odunsi et al. (1999). Different protein levels had no significant $(\mathrm{P}<0.05)$ effect on serum triglycerides, cholesterol and glucose of Japanese quails. This may be due to that quails in all groups fed on the same diet have $3200 \mathrm{kcal} \mathrm{ME} / \mathrm{kg}$ diet.

\section{Economical evaluation:}

The data of economical evaluation of quail performance revealed that feeding diets containing 22 and $24 \%$ protein had improved economic feed efficiency compared with other experimental groups. Priority of economical feed efficiency in the third and fourth groups may be due to better feed and energy utilization and conversion.

It could be concluded that, quails fed on diet containing $3200 \mathrm{kcal}$ $\mathrm{ME} / \mathrm{kg}$ with $22 \%$ crude protein, supplemented with limiting amino acids, recorded the best results in weight gain, feed conversion, in addition to economical feed efficiency.

\section{REFERENCES}

Adeyemo, A.I. (2000): Response of pullets fed varying levels of dietary protein. Proceedings annual conference of Animal Production Society of Nigeria, 123-125.

Aggoor, F.A.M.; Attia, Y.A. and Qota, E.M.A. (2000): A study on the energetic efficiency of different fat sources and levels in broiler chick vegetable diets. J. Agric. Sci., Mansoura, Univ., 25: 801-820.

Angulo, E.; Brufau, J.; Miquel, A. and Esteve-Garcia, (1993): Effect of diet density and pelleting on productive parameters of Japanese quail. Poultry Science, 72: 607-610.

Annaka, A.; Tomizawa, K.; Momose, Y.; Watabe, E. and Ishibasi, T. (1993): Effect of dietary protein levels on performance of Japanese quails. Animal Science and Technology 64: 797-806.

AOAC (1990): Association of Official Analytical Chemists. Official Methods of Analysis $\left(14^{\text {th }} \mathrm{Ed}\right.$.) AOAC, Washington, DC.

Baker, D.H. (2003): Ideal amino acid patterns for broiler chicks. In: Amino Acids in Animal Nutrition, $2^{\text {nd }}$ edition, ed. J. P.F.D' Mello, CABI publishing, Wallingford, Oxon, UK, pp.223-235.

Baker, D.H. and Han, Y. (1994): Ideal amino acids profile for chicks during the first three weeks post hatching. Poultry Science, 73: 1441-1447. 
Baldini, J.T.; Roberts, R.E. and Kirkpatrick, C.M. (1995): A study of the protein requirements of bobwhite quail reared in confinement in battery brooders to 8 weeks of age. Poult. Sci. 29: 161-166.

Belay, T. and Teeter, R.G. (1996): Virginiamycin and caloric density effects on live performance, blood serum metabolite concentration and carcass composition of broiler reared in thermoneutral and cycling ambient temperatures. Poultry Sci., 75: 1383-1392.

Djouvinov, D. and Mihailov, $R$. (2005): Effect of low protein level on performance of growing and laying Japanese quails (Coturnix Coternix Japonica). Bulgarian Journal of Veterinary Medicine, 8, No 2: 91-98.

Dublecz, K.; Vincze, L.; Szuts, G.; Wagner, L.; Pal, L.; and Bartos, A. (1999): Effect of dietary energy level on the performance of broiler chicks. Proceedings $12^{\text {th }}$ European symposium on poultry nutrition. WPSA-Velthoven, The Nederland, 15-19 August 1999: 424-426.

Emmert, J.L. and Baker, D.H. (1997): Use of the ideal protein concept for precision formulation of amino acid levels in broiler diets. Journal of Applied Poultry Research, 6: 462-470.

Han, Y.; Suzuki, H.; Parsons, C.M. and Baker, D.H. (1992): Amino acid fortification of low- protein corn and soybean meal diet for chicks. Poult. Sci., 71: 1168-1178.

Hashiguchi, M. and Yamamoto, Y. (2006): Effect of dietary protein levels on body growth and carcass fat and protein deposition in female Japanese quail. University farm, Faculty of Agriculture, Kagawa University, Sanuki-Shi, Kagawa 769-2304, Japan.

Hashiguchi, M.; Mahipala, M.B.P. and Kamisoyama, H. (1998): Influence of low protein diets on sexual maturity and body characteristics in female Japanese quail. Proceedings of $6^{\text {th }}$ Asian Pacific Poultry Congress, 408-409.

Ismail, F.S.A.; Attia, Y.A.; Aggoor, F.A.M.; Qota, E.M.A.E. and Shakmak, E.A. (2006): Effect of energy level, rice by products and enzyme addition on carcass yield, meat quality and plasma constituents of Japanese quail. EPC 2006 XII European Poultry Conference, Verona, Italy 10-14 September.

Kassim, H. and Suwanpradit, S. (1996): The effect of energy levels on the carcass composition of the broilers. Asian J. Anim. Sci., 9: 331-335. 
Kaur, S.; Mandal, A.B.; Singh, K.B. and Kadam, M.M. (2008): The response of Japanese quails (heavy body weight line) to dietary energy levels and graded essential amino acid levels on growth performance and immuno-competence. J. Life. Sci., 61: 1-8.

Kul, S.; Seker, I. and Yildirim, O. (2006): Effect of separate and mixed rearing according to sex on fattening performance and carcass characteristics of Japanese quails (Coturnix coturnix japonica). Arch. Tierz., 49 (6): 607-614.

Lehman, G.P. and Henry, J.B. (1984): Clinical diagnosis and management by laboratory methods. 17 ed., pp. 1431-1438.

Lippens, M.; HuyGhebaert, G. and Groote, G. (1997): Laageiwitrantsoenen en aminozuurbehoeften bij vleeskippen. Brochure Ministerie van Middenstand en Landbouw, Dients voor Landbouwkundig onderzoek, pp. 86.

Marks, H.L. (1993): Carcass composition, feed intake and feed efficiency following iong-term selection for four-week body weight in Japanese quail. Poultry Science 72: 1005-1011.

Moran, E.T.; Bushang, R.D. and Bhlgili, S.F. (1992): Reducing dietary protein and for broiler while satisfying amino acid requirements by least-cost formulation: Live performance, litter composition, and yield of fast-food carcass cuts at six weeks. Poult. Sci., 71: 1687-1694.

$N R C$ (1994): Nutrients requirements of poultry, $8^{\text {th }}$ ed. National Acad. Press, Washington, DC.

Odunsi, A.A.; Tonifade, A.A. and Babatunde, G.M. (1999): Response of broiler chicks to virginiamycin and dietary protein concentrations in the humid tropics. Arch. Zootec., 48:317-325

Ozek, K. (2006): The optimum protein content in high-Energy starter diet for Chukar Partridge (Alectoris chukar chukar). International Journal of poultry Science 5 (6): 522-525.

Ozek, K.; Yazgan, O. and Bahtiyarca, Y. (2003): Effects of dietary protein and energy concentrations on performance and carcass characteristics of chukar partridge (Alectoris chukar) raised in captivity. Br. Poult. Sci., 3: 419-426.

Plavnik, I.; Wax, E.; Sklan, D.; Bartov, I. and Hurwitz, S. (1997): The response of broiler chickens and turkey poults to dietary energy supplied either by fat or carbohydrates. Poult. Sci., 76: 1000-1005. 
Raiz, S. and Alam, S.S. (2006): Evaluation of nutritive value of different levels of chrome shaving (hydrolyzed) partially replacing animal protein in the feed on the performance of quail chicks. Journal of Agricultural and Biological Science, Vol.1, No.1, July 2006.

Saleh, E.A.; Watkins, S.E.; Waldroup, A.L. and Waldroup, P.W. (2004): Effect of dietary nutrient density on performance and carcass quality of male broilers grown for further processing. Int. J. Poult. Sci., 3: 1-10.

SAS Institute (1995): SAS-User's Guide: Statistics. Version 6, $4^{\text {th }}$ ed. SAS Institute Inc., Cary, NC., USA.

Seker, I.; Kul, S. and Bayraktar, M. (2009): Effect of group size on fattening performance, mortality rate, slaughter and carcass characteristics of Japanese quails (Coturnix coturnix japonica). J. of Anim. Vet. Advances, 8 (4): 688-693.

Shrivastava, A.K. and Panda, B. (1999): A review of the nutrition of Japanese quail. World Poult. Sci. J. 55: 73-81.

Skinner, J.T.; Waldroup, A.L. and Waldroup, P.W. (1992): Effects of dietary nutrient density on performance and carcass quality of broilers 42 to 49 days of age. J. Appl. Poult. Res., 1: 367-372.

Tarasewicz, S.; Szczerbinska, D.; Ligocki, M.; Wiercinska, M.; Majewska, D. and Romaniszyn, K. (2006): The effect of differentiated dietary protein level on the performance of breeder quails. Animal Science Paper and Reports, vol.24, No.3: 207-216.

Vohra, P. (1993): Feeding of Game birds. Game bird Workshop. University of California, Davis, Campus, 55, Roessler, USA.

Vohra, P. and Roudybush, P. (1971): Protein requirements of Coturnix quail of 6 weeks of age. Poult. Sci., 50: 1081-1084.

Weber, C.W. and Reid, B.L. (1967): Protein requirements of Coturnix quail of 5 weeks of age. Poult. Sci., 46: 1190-1194.

Woodard, A.E.; Vohra, P. and Snyder, R.L. (1977): Effect of protein in the diet on the growth of pheasant. Poult. Sci., 56: 1492-1500.

Yee, H.Y. (1968): Clinical Chemistry, 14:898. 